JOANNA RAJEWSKA DE MEZER

Uniwersytet im. Adama Mickiewicza

w Poznaniu

\title{
PRACA SOCJALNA I PORADNICTWO PRAWNE W POMOCY RODZINOM DYSFUNKCYJNYM
}

ABSTRACT. Rajewska de Mezer Joanna, Praca socjalna i poradnictwo prawne w pomocy rodzinom dysfunkcyjnym [Social Work and Legal Guidence as a Support for Disfunctional Families]. Studia Edukacyjne nr 42, 2016, Poznań 2016, pp. 381-401. Adam Mickiewicz University Press. ISSN 1233-6688. DOI: $10.14746 /$ se. 2016.42 .22

The influence of parents, families on the development of the individual and social identity of their child is extremely important. In the process of primary socialization, child acquires patterns of social roles, which modifying plays in its adulthood.

Dysfunctional family is not able to perform its functions (socialization, educational, protective) properly, what can be harmful for children. In order to prevent child from the negative effects of dysfunction, family should be covered with a professional help. This assistance should base on the principle of subsidiarity and stimulates family to cooperation and activity in the exit of a difficult situation. Support in this area provide social assistance entities, using social work and legal advice. This form of support can equip the beneficiary professional knowledge, allow him to realize the cause of the problem. It has also educational character.

Key words: dysfunctional family, socialization, social care, social work, specialist advice, legal advice

W wyobrażeniach i pragnieniach większości z nas pojęcie rodziny wiąże się z poczuciem bezpieczeństwa, ciepła i atmosfery sprzyjającej rozwojowi, ze środowiskiem, do którego powraca się świętując sukcesy osiągane przez jednostkę na różnych płaszczyznach jej działalności, jak i po to, by znaleźć oparcie oraz schronienie psychiczne w sytuacji porażki czy niepowodzenia.

Obecnie, w dobie dynamicznych zmian w różnych dziedzinach życia społeczego, gospodarczego, politycznego, redefiniujemy pojęcia relacji międzyludzkich, bliskości, rodziny. Rozważamy ich znaczenie oraz funkcje, jakie pełnią dla współczesnego człowieka i społeczeństwa. Naszą uwagę 
skupia także problematyka związana z dysfunkcją rodziny, celowym lub niezamierzonym niewykonywaniem, bądź niewłaściwym wykonywaniem przypisanych jej społecznie lub prawnie zadań oraz możliwością wsparcia rodziny przez państwo i działajace $\mathrm{w}$ jego imieniu podmioty ustawowo zobligowane do świadczenia pomocy.

Celem podjętych $\mathrm{w}$ niniejszej pracy rozważań jest próba odpowiedzi na pytanie dotyczące znaczenia pomocy o charakterze niepieniężnym, świadczonej $\mathrm{w}$ formie pracy socjalnej i poradnictwa specjalistycznego, rodzinie niewypełniającej właściwie swoich funkcji. Pomoc, o której mowa, stanowi pewną ingerencję $\mathrm{w}$ funkcjonowanie autonomicznej grupy społecznej, jaką stanowi rodzina, jednak jej udzielenie postrzegane jest jako niezbędny warunek podjęcia przez jej członków właściwego wykonywania zadań związanych z wykonywaniem roli społecznej w rodzinie (np. roli ojca, matki, małżonka, partnera w związku).

Rozważania należy rozpocząć od zdefiniowania pojęcia rodziny, czynionego z uwzględnieniem odmienności definicyjnie wynikających ze specyfiki różnych dziedzin nauki, w których zainteresowaniu znajduje się podniesiony w pracy problem. $Z$ uwagi na podjęty temat należy także prześledzić opisywane $\mathrm{w}$ literaturze przedmiotu funkcje i zadania przypisywane rodzinie oraz przyczyny wystąpienia dysfunkcji (problemów i niewydolności wychowawczej rodziców), bowiem od właściwej diagnozy stanu faktycznego zależy podjęcie działań pomocowych, dostosowanie ich do zindywidualizowanych potrzeb jednostek budujacych rodzinę, a co z tym związane uzyskanie oczekiwanej efektywności. Niedocenianą formą działań wspierających rodzinę, opartą na pracy na potencjale tkwiącym w grupie rodzinnej, jest tytułowa praca socjalna, wsparta specjalistycznym poradnictwem prawnym, rodzinnym i psychologicznym, którym to poświęcona jest druga część niniejszego artykułu.

Pojęcie rodziny, jak już wspomniano, definiowane jest $\mathrm{w}$ rozmaity sposób - w ujęciach szerszym i węższym, z zaakcentowaniem elementów właściwych dla obranych pryzmatów rozważań. Powszechna Deklaracja Praw Człowieka ONZ, będąca aktem prawnym o chatrakterze międzynarodowym, definiuje rodzinę jako naturalna i fundamentalna jednostkę społeczeństwa, podlegającą ochronie ze strony tegoż społeczeństwa i państwa ${ }^{1}$. Można ją określić

(...) jako małą grupę pierwotną złożoną z osób, które łączy stosunek małżeński i rodzicielski oraz silna więź międzyosobnicza².

${ }^{1}$ Art. 16 ust. 3 Powszechnej Deklaracji Praw Człowieka ONZ.

2 S. Kawula, J. Brągiel, A.W. Janke, Pedagogika rodziny, Toruń 2002, s. 11. 
Rodzinie nadaje się miano prymarnej instytucji wychowania i uznaje za pierwsze źródło przekazu symbolicznego, tak istotnego mechanizmu procesu socjalizacji. Stanowi ona

(...) małą i jednocześnie pierwotną grupę społeczną o swoistej organizacji i określonym układzie ról między poszczególnymi członkami, związaną wzajemną odpowiedzialnością moralną, świadomą własnej odrębności, mającą swe tradycje i przyzwyczajenia, zespoloną miłością i akceptującą się nawzajem³.

Tworza ją osoby, które nawzajem zaspokajają swoje potrzeby materialne, uczuciowe, społeczne i duchowe. Jest więc wspólnotą, a jej członkowie stawiają sobie określone cele, które współdziałając realizująa

$\mathrm{W}$ ujęciu pedagogicznym rodzina postrzegana jest jako środowisko i zarazem system edukacyjny oraz instytucja socjalizacyjno-wychowawcza, jak również wspólnota emocjonalno-kulturowa ${ }^{5}$. Umożliwia dziecku wypracowywanie poprawnych zachowań i reakcji społecznych ${ }^{6}$. Dla pojęcia rodziny istotny jest kontekst rozwojowy jednostki o szczególnej wadze dla rozwoju indywidualnego dziecka we wczesnym dzieciństwie, który odnosi się również do zmian i przekształceń rozwojowych psychiki oraz zachowań człowieka w późniejszych okresach ontogenezy, włączając w to okres dorosłości. Kontekst ten ma znaczenie dla rozwoju jednostki, dając jej umiejętność uczenia się od osób, z którymi łączy je więź społeczno-emocjonalna7.

Rodzina pełni szereg istotnych funkcji w życiu człowieka. Funkcjami rodziny są role, jakie winna ona spełniać dla społeczeństwa, jak i dla budujących ją osób oraz cele i zadania, do których realizacji dążą działania jej członków ${ }^{8}$.

Literatura przedmiotu ukazuje wiele klasyfikacji funkcji rodziny opartych na różnych czynnikach, takich jak: liczba obowiązków i zadań przypisywanych rodzinie, czy odmienna terminologia.

Z. Tyszka wymienił dziesięć funkcji rodziny, łącząc je w cztery grupy o charakterze podstawowym. Do pierwszej z nich zaliczył funkcje biopsychiczne (prokreacyjną oraz seksualną). Drugą grupę stanowią funkcje ekonomiczne: materialno-ekonomiczna oraz opiekuńczo-zabezpieczająca. Na-

\footnotetext{
${ }^{3}$ I. Rembowski, Więzi uczuciowe w rodzinie. Studium psychologiczne, Warszawa 1972, s. 16.

${ }^{4}$ W. Sztander, Rodzina z problemem alkoholowym, Warszawa 2006, s. 5.

5 D. Lalak, T. Pilch (red.), Elementarne pojęcia pedagogiki społecznej i pracy socjalnej, Warszawa 1999, s. 236.

${ }^{6}$ B. Matyjas, Pedagogika społeczna i rodzina - obszary badań, [w:] Pedagogika społeczna podrecznik akademicki, t. II, red. E. Marynowicz-Hetka, Warszawa 2007, s. 505.

7 B. Harwas-Napierała, Rodzina jako wartość w rozwoju człowieka, Poznań 2009, s. 13-14.

${ }^{8} \mathrm{H}$. Bednarski, Rodziny polskie w procesie przemian, [w:] Wybrane obszary dysfunkcjonalności rodziny, red. M. Dudek, Krasnystaw 2010, s. 12.
} 
stępna grupa skupia funkcje społeczno-wyznaczające (tj. funkcję klasową oraz legalizacyjno-kontrolną). Na ostatnią grupę składają się funkcje socjopsychologiczne (a wśród nich tak istotne funkcje: socjalizacyjna, kulturalna, rekreacyjno-towarzyska oraz emocjonalno-ekspresyjna) ${ }^{9}$.

M. Ziemska oprócz funkcji prokreacyjnej, opiekuńczej, czy socjalizującej, jaką wypełniać powinna rodzina, wyróżniła też funkcje psychohigieniczną, którą odniosła do poczucia bezpieczeństwa, stabilności emocjonalnej oraz odpowiednich warunków do rozwoju osobowości człowieka. Podkreśliła wagę zdrowia psychicznego członków rodziny i ich potrzebę istnienia w harmonii ${ }^{10}$.

F. Adamski zaproponował natomiast funkcję instytucjonalną (na którą składają się funkcje: prokreacyjna, ekonomiczna, opiekuńcza, socjalizacyjna, stratyfikacyjna oraz integracyjna) oraz funkcję osobową rodziny (w tym małżeńską, rodzicielską oraz braterską) ${ }^{11}$.

Jak wynika z powyższego przeglądu funkcji przypisywanych rodzinie, dotyczą one różnych sfer życia człowieka, a co z tym związane - możliwość udzielenia rodzinie właściwej pomocy, w sytuacji wystąpienia dysfunkcji, zależy od rozpoznania obszaru i zakresu niedomogów. Dopiero diagnoza stanu faktycznego pozwala na włączenie pomocy, w tym pracy socjalnej z jednostką i rodziną oraz specjalistycznego poradnictwa.

Warta rozważenia, z punktu widzenia podjętego tematu, jest funkcja socjalizacyjna rodziny. Wychowujący dziecko rodzice wpływają na jego kształtowanie jako jednostki o indywidualnych dążeniach, ale zarazem jako członka budującego społeczeństwo. Rodzina realizuje prawo do prywatności, indywidualność, ale zarazem współdziała z szeregiem instytucji społecznych czy oświatowych, wprowadzając dziecko w życie społeczne. Socjalizacja $\mathrm{w}$ rodzinie rozumiana jest jako wychowywanie dzieci w określonych normach, zasadach, które jednocześnie są akceptowalne w danej społeczności, w której ta rodzina żyje ${ }^{12}$.

Proces socjalizacji stanowi jeden z podstawowych i najważniejszych procesów kształtowania człowieka. W jego toku kształtuje się zarówno osobowość, jak i tożsamość jednostki ludzkiej, która zyskuje przymiot istoty społecznej. W ramach tego procesu człowiek nabywa i przyswaja umiejętności, które leżą u podstaw wszelkich interakcji społecznych, w tym wiedzę doty-

${ }^{9}$ Z. Tyszka, Socjologia rodziny, Warszawa 1974, s. 69.

${ }^{10}$ M. Ziemska, Rodzina a osobowość, Warszawa 1975, s. 35-38.

${ }^{11} \mathrm{~F}$. Adamski, Socjologia matżeństwa i rodziny, Warszawa 1982, s. 49-61.

${ }^{12} \mathrm{H}$. Cudak, Zewnętrzne uwarunkowania wewnątrzrodzinnej socjalizacji i wychowania dzieci, [w:] Wokót wychowania. Rola rodziny $i$ szkoty w procesie socjalizacji dziecka, red. T. Rostowska, J. Rostowski, Łódź 2006, s. 42-43. 
czącą norm, wzorów zachowań i reakcji emocjonalnych oraz podstawowych wartości ${ }^{13}$.

S. Kowalski posłużył się pojęcim uspołecznienia, pojmowanym szerzej jako „wchodzenie w kulturę”, czyli akulturacją, ale także jako kształtowanie osobowości społecznej albo nabywanie społecznej dojrzałości oraz kompetencji społecznych ${ }^{14}$. Socjalizacja bywa utożsamiana ze "spontanicznymi procesami przystosowania społecznego", w odróżnieniu od wychowania stanowiącego celowe i planowe oddziaływania. Inni autorzy natomiast proces wychowania oraz socjalizacji stawiają w relacji nadrzędności i podrzędności - w której wychowanie jest częścią szerokiego procesu socjalizacji.

Można powiedzieć, iż socjalizacja jest procesem, który trwa przez całe życie człowieka. Jednostka uczy się nowych wzorów zachowań, koryguje i modyfikuje dotychczasowe, funkcjonując w społeczeństwie i dostosowując się do jego oczekiwań. Konfiguracje wzorów zachowania odnoszące się do rozmaitych usytuowań ludzi w zbiorowościach noszą nazwę ról społecznych ${ }^{15}$.

Nabywanie $\mathrm{w}$ procesie socjalizacji umiejętności opiera się na opisywanych w literaturze mechanizmach: wzmacnianiu (przez nagradzanie zachowań właściwych oraz karanie niewłaściwych, czy niepożądanych), naśladowaniu (czyli zachowaniach podobnych, powielanych za innymi) oraz mechanizmie przekazu symbolicznego (polegającym na pouczeniach słownych, czy zawartych w tekście pisanym) ${ }^{16}$. Dlatego tak istotne jest korygujące, pomocowe oddziaływanie na rodzinę dysfunkcyjną, praca z nią podejmowana przez profesjonalne podmioty (pracowników socjalnych, terapeutów, psychologów), aby korygować błędy popełniane przez najbliższych dziecku "znaczących innych" i minimalizować ich niepożądany wpływ na przebieg procesu socjalizacji małoletniego.

Należy pamiętać, że proces socjalizacji człowieka dzieli się na dwa okresy: pierwotny i wtórny. Niezwykle istotny jest pierwszy okres, nazwany socjalizacją pierwotną, uważany za etap zasadniczy omawianego procesu. W okresie tym, na który składa się dzieciństwo człowieka, jednostka ludzka nabywa elementarnych wzorów zachowań i podstawowych ról społecznych oraz zdobywa wiedzę niezbędną jej do prawidłowego funkcjonowania $\mathrm{w}$ społeczeństwie. Praca socjalna $\mathrm{z}$ rodziną $\mathrm{w}$ tym okresie, pomoc jej we właściwym wypełnianiu swoich funkcji, ma znaczenie dla dalszego funkcjonowania społecznego i rozwoju dziecka.

${ }^{13}$ B. Szacka, Wprowadzenie do socjologii, Warszawa 2003, s. 138.

${ }^{14}$ S. Kowalski, Socjologia wychowania w zarysie, Warszawa 1974, s. 297-300.

${ }^{15}$ B. Szacka, Wprowadzenie do socjologii, s. 139.

16 Tamże, s. 138. 
Socjalizacja pierwotna jest początkową fazą procesu socjalizacji, fazą przystosowania, stanowiącą wstępne stadia wchodzenia jednostki w nowe grupy i role społeczne ${ }^{17}$, a w tej fazie jednostka odtwarza, odwzorowuje przypisywane jej i oczekiwane przez grupę role społeczne. Dopiero w późniejszych fazach procesu socjalizacji (uspołecznienia) lub po wnikliwym opanowaniu (wyuczeniu się) przypisanych jej ról, przeciwstawia własną, często twórczo zmodyfikowaną koncepcję pełnienia tych ról bądź też opanowuje nowe wartości i wzory zachowań ${ }^{18}$. Socjalizacja pierwotna przebiega $\mathrm{w}$ atmosferze nasyconej uczuciami wynikającymi z rodzinnych więzi emocjonalnych łączących rodziców i ich dziecko. Rodzice, istniejący w życiu dziecka od początku jego życia, wpływający na przekazywanie mu zasad, podstawowych wartości, kształtowanie jego tożsamości, nazywani są w literaturze przedmiotu tzw. „znaczącymi innymi”19.

Do fazy „kreowania ról społecznych” zalicza się także socjalizację wtórną, stanowiącą drugi i zarazem ostatni etap socjalizacji jednostki, którego celem jest wprowadzenie człowieka $\mathrm{w}$ poszczególne segmenty życia społecznego. Stanowi ona istotny etap w procesie kształtowania i modyfikowania roli społecznej jednostki ludzkiej, natomiast jej skuteczność uwarunkowana jest możliwością odwołania się do poznawczych i normatywnych schematów, przyswojonych przez jednostkę $w$ okresie powołanej wyżej socjalizacji pierwotnej20. Jest związana z poznawaniem złożoności świata, a także różnych wariantów i modeli życia.

Można więc powiedzieć, że poprawny przebieg procesu socjalizacji wtórnej, stanowiącego fazę opartego na doświadczeniu kreowania i modyfikowania ról, zależny jest od przebiegu procesu socjalizacji pierwotnej i jego początkowej fazy, jaką jest przystosowanie.

Rodzina integrując się z innymi grupami społecznymi oraz poprzez pełnienie przypisanych jej funkcji oddziałuje na kształtowanie i modyfikowanie zachowań społecznych. Natomiast społeczeństwo wywiera wpływ na funkcjonowanie jednostki i budowanej przez nią rodziny. Oddziaływanie to może być pozytywne, prowadzące do zachowania wartości i zasad, ale może także, niestety, mieć skutki destrukcyjne, zaburzające prawidłowe funkcjonowanie rodziny ${ }^{21}$.

17 W. Ambrozik, Readaptacja społeczna i reorganizacja środowisk lokalnych jako warunek skuteczności oddziatywań resocjalizacyjnych, [w:] Resocjalizacja, t. 2, red. B. Urban, J.M. Stanik, Warszawa 2007, s. 182-183.

18 Tamże, s. 183.

${ }^{19}$ B. Szacka, Wprowadzenie do socjologii, s. 152 i n.

${ }^{20}$ K. Olechnicki, P. Załęski, Stownik socjologiczny, Torun 2000, s. 189-190.

${ }^{21}$ Szerzej J. Rajewska de Mezer, Rola poradnictwa specjalistycznego we wsparciu rodziny w funkcji wychowawczej, [w:] Młodzież między ryzykiem a ochrona. Formy wsparcia psychopedagogicznego dla adolescentów, red. A. Matysiak-Błaszczyk, B. Jankowiak, Poznań 2017 (w druku). 
Czynniki charakteryzujace współczesne warunki życia, a wśród nich anonimowość jednostki w społeczeństwie, doprowadziły do ograniczenia realizowania przez rodzinę funkcji kontrolnej. Swego rodzaju izolacji rodziny od otoczenia społecznego oraz zwiększeniu zakresu jej intymności towarzyszy wzrost znaczenia funkcji emocjonalno-ekspresyjnej22.

Przemiany będące skutkiem transformacji ustrojowej i społecznogospodarczej w Polsce spowodowały zaburzenia adaptacyjne dużej części, przyzwyczajonego do innych realiów funkcjonowania, społeczeństwa. Nowe warunki dyktowane przez rynek pracy, mający cechy gospodarki wolnorynkowej, przyczyniły się do powstania problemów z zatrudnieniem znacznej liczby obywateli. Posiadanie stabilnej pracy przestało być regułą, stało się dobrem deficytowym, którego zdobycie i utrzymanie zależne jest od posiadania coraz wyższych kompetencji i ciągłego ich podnoszenia. U wielu osób reakcją na nieumiejętność poradzenia sobie z przeciwnościami życiowymi (brakiem zatrudnienia, środków do życia) są ujawniające się i rozwijające choroby zaburzeń psychicznych (np. depresje, nerwice itp.).

Powyższe wpływa na zaburzenia $\mathrm{w}$ wykonywaniu innych ról społecznych, jak na przykład tak istotnej roli w rodzinie - męża, żony, partnera, ojca, matki, córki itp. Rodzina nie wypełnia wówczas przypisanych jej funkcji, między innymi opiekuńczej, zabezpieczającej, czy socjalizacyjnej - staje się dysfunkcyjna i wymaga konstruktywnego wsparcia. Przekazywane zstępnym wzory ról społecznych są niewłaściwe, niepożądane, a ich powielanie zagraża przenoszeniem na kolejne pokolenia patologicznego w swym charakterze sposobu funkcjonowania.

Sytuacja powyższa wymaga szerokiego, wieloaspektowego wsparcia rodziny w wypełnianiu przypisanych jej funkcji. Pomoc, o której mowa musi być jednak udzielana $\mathrm{w}$ sposób profesjonalny, ze świadomością autonomii rodziny i przysługującego jej prawa do wychowania dzieci zgodnie z własnymi przekonaniami ${ }^{23}$, przy jednoczesnym rozpatrywaniu wszelkich podejmowanych wobec rodziny działań, przez pryzmat zasady dobra dziecka.

Ustawa zasadnicza, jaką jest Konstytucja Rzeczpospolitej Polskiej, pozwala na podjęcie działań pomocowych o charakterze ingerencyjnym $\mathrm{w}$ autonomię rodziny, $\mathrm{w}$ zakresie wykonywanych przez nią funkcji wychowawczych, w sytuacjach i na warunkach określonych we właściwych przepisach. Natomiast aktem prawnym, w którym uregulowana została kwestia

22 G. Cęcelek, Rodzina - jej problemy oraz zagrożenia wychowawcze, Mazowieckie Studia Humanistyczne, 2005, 1-2, s. 247.

${ }^{23}$ Art. 48 Konstytucji Rzeczpospolitej Polskiej z 2 kwietnia 1997 r. (DzU 1997, nr 78, poz. $483)$. 
dotycząca form ingerowania $\mathrm{w}$ wykonywanie władzy rodzicielskiej jest ustawa Kodeks rodzinny i opiekuńczy24.

Zasadą prymarną, przewidzianą przez przepisy prawa rodzinnego i opiekuńczego, którą należy uwzględniać przy interpretowaniu poszczególnych jego regulacji, przeprowadzając proces subsumpcji, jest zasada dobra dziecka. Właśnie ona pozwala na ingerencje w wykonywanie władzy rodzicielskiej nad dziećmi $\mathrm{w}$ rodzinie, $\mathrm{w}$ celu przeciwdziałania występowaniu sytuacji niepożądanych, godzących $\mathrm{w}$ dobro dziecka ${ }^{25}$, a polegających na nadużyciach wobec dzieci (stosowanie aktów przemocy psychicznej lub fizycznej) oraz zaniedbaniach, które naruszają ich prawa.

Kodeks rodzinny i opiekuńczy przewiduje możliwość zaingerownia w wykonywanie przez rodziców władzy rodzicielskiej przez jej ograniczenie, zawieszenie lub pozbawienie ${ }^{26}$. Decyzja o zastosowaniu jednej z wyżej wymienionych form działania formalnego, ograniczających decyzyjność rodziców wobec ich dzieci w różnych aspektach ich życia, zależna od oceny stanu faktycznego i zdiagnozowanego stopnia nieprawidłowości, powodowana jest brakiem właściwego wykonywania władzy rodzicielskiej nad dzieckiem.

Rodzice, których dotyczy powyższy problem wymagają pomocy we właściwym wykonywaniu obowiązków rodzicielskich. Nieprawidłowości w omawianym zakresie nie zawsze stanowią wyraz złej woli rodziców, będąc intencjonalnymi działaniami, noszącymi cechy nadużyć wobec dziecka, czy rażących zaniedbań. Często są one wynikiem braku dostatecznych kompetencji, wiedzy na temat dziecka, jego rozwoju, przebiegu procesu wychowania i są powodowane czynnikami zdrowotnymi (niepełnosprawnością fizyczną i intelektualną) oraz niewłaściwym przebiegiem procesu socjalizacji rodziców dziecka.

Ingerencja państwa $\mathrm{w}$ wykonywanie władzy rodzicielskiej musi być wsparta działaniami pomocowo-korygującymi. Prawo polskie przewiduje konieczność instytucjonalnego wsparcia rodziny, w której występuje negatywna w skutkach dysfunkcja.

Sąd opiekuńczy i inne organy władzy publicznej w ramach działań pomocowych zawiadamiają właściwy podmiot ${ }^{27}$ o potrzebie udzielenia rodzinie dziecka odpowiedniej pomocy. Ta regulacja rodzi dla podmiotu udziela-

${ }^{24}$ Ustawa z 25 lutego 1964 r. Kodeks rodzinny i opiekuńczy (DzU 2015, poz. 2082 ze zm.).

${ }^{25}$ M. Andrzejewski, Prawo rodzinne i opiekuńcze, Warszawa 2014, s. 24.

${ }^{26}$ Art. 109, art. 110 i art. 111 Ustawy Kodeks rodzinny i opiekuńczy (DzU 2015, poz. 2082 ze zm.).

27 Zgodnie z Ustawą z 9 czerwca 2011 r. o wspieraniu rodziny i systemie pieczy zastępczej (DzU 2015, poz. 332 ze zm.) - jednostkę organizacyjną wspierania rodziny i systemu pieczy zastępczej. 
jącego wsparcia obowiązek informowania sądu o rodzajach udzielanej pomocy oraz jej efektach ${ }^{28}$. Z uwagi na wieloaspektowość problemu wsparcia rodziny dysfunkcyjnej i konieczność współdziałania różnych instytucji państwa, przepisy nakładają także na podmioty działające $w$ systemie pomocy społecznej formalny oblig współpracy z kuratorem sądowym ustanowionym dla objętej oparciem rodziny.

Konieczność pomocy rodzinie, skorygowania sposobu wykonywania przez nią władzy rodzicielskiej, pozwalająca na ingerowanie w decyzje konkretnej dysfunkcjonalnej rodziny, musi być oparata na określonych zasadach. Prymarna, w tym znaczeniu, jest fundamentalna dla pomocy społecznej zasada pomocniczości. Charakterystyczne dla niej jest wspieranie jednostki w wyjściu z trudnej sytuacji przez budowanie jej samodzielności i samoaktywności, nie zaś przejmowanie przypisanych jej funkcji i zadań29. Konieczna jest diagnoza umożliwiająca zbadanie posiadanego przez jednostkę czy rodzinę potencjału, z użyciem którego są one w stanie przezwyciężyć napotkane w życiu trudności.

W myśl art. 2 ust. 1 Ustawy o pomocy społecznej

pomoc społeczna jest instytucją polityki społecznej państwa, mającą na celu umożliwienie osobom i rodzinom przezwyciężenie trudnych sytuacji życiowych, których nie są one w stanie pokonać, wykorzystując własne uprawnienia, zasoby i możliwości ${ }^{30}$.

W taki sposób rozumianej pomocy społecznej możemy wyróżnić trzy podstawowe cele operacyjne. Pierwszy stanowi zaspokojenie niezbędnych potrzeb życiowych osób i rodzin i umożliwienie im bytowania w warunkach odpowiadających godności człowieka. Następny polega na życiowym usamodzielnieniu beneficjentów oraz pomocy im $w$ integracji ze środowiskiem. Natomiast kolejnym celem podejmowanej w ramach działania pomocy społecznej jest zapobieganie powstawaniu trudnych sytuacji życiowych stanowiących jedną z przesłanek nabycia pomocy ${ }^{31}$.

Ustawa o pomocy społecznej $\mathrm{w}$ art. 3 nawiązuje do opisanej już zasady pomocniczości utrzymując, iż świadczona pomoc powinna polegać na wspieraniu osób i rodzin $\mathrm{w}$ wysiłkach zmierzających do umożliwienia im życia w warunkach odpowiadających godności człowieka ${ }^{32}$.

28 Por. art. 100 §1 i 2 Ustawy Kodeks rodzinny i opiekuńczy (DzU 2015, poz. 2082 ze zm.).

${ }^{29} \mathrm{~J}$. Rajewska de Mezer, E. Flaga, Rola edukacyjna pomocy społecznej we wsparciu rodzin osob niepetnosprawnych, Studia Edukacyjne, 2013, 26, s. 151.

${ }^{30}$ Ustawa z 12 marca 2004 r. o pomocy społecznej (DzU 2016, poz. 930 ze zm.).

${ }^{31}$ T. Kaźmierczak, Polityka pomocy społecznej wobec rodziny we wspótczesnej Polsce, [w:] Praca socjalna. Pomoc społeczna, red. J. Kwaśniewski, Katowice 1998, s. 249.

32 Art. 3 ust. 1 Ustawy z 12 marca 2004 r. o pomocy społecznej. 
Działanie przez pryzmat zasady pomocniczości znajduje swoje potwierdzenie także $\mathrm{w}$ orzecznictwie sądowym. Zgodnie z wyrokiem Wojewódzkiego Sądu Administracyjnego w Lublinie z 17 stycznia 2008 roku: pomoc społeczna wymaga zdiagnozowania zaistnienia dwóch przesłanek: wystąpienia trudnej sytuacji życiowej oraz niemożliwości jej samodzielnego przezwyciężenia. Udzielenie pomocy społecznej następuje po wyczerpaniu przez osobę i rodzinę własnych uprawnień, środków, zasobów i możliwości. Wynika to z podstawowej zasady systemu pomocy społecznej, jaką jest zasada pomocniczości, która oznacza, że organ pomocy społecznej nie ma obowiązku uczestniczyć w ponoszeniu całości kosztów utrzymania strony wnioskującej o pomoc ${ }^{33}$.

Świadomość konieczności przestrzegania zasady pomocniczości jest niezwykle ważna przy konstruowaniu planu pomocy rodzinie dysfunkcyjnej. Zachwianie równowagi pomiędzy udzielaniem pomocy a podejmowaniem działania samopomocowego przez beneficjentów rodzi groźbę wycofania z ich strony, utraty kompetencji, zrzeczenia się decyzyjności i przerzucenia odpowiedzialności za swoją sytuację na pomagającego. Problem ten jest szczególnie istotny w przypadku pracy z rodziną, wobec której zastosowano środki o charakterze ingerencji we władzę rodzicielską, polegające na umieszczeniu dziecka poza rodziną, w pieczy zastępczej. Sytuacja ta powoduje powstanie zagrożenia zaprzestania przez rodziców podejmowania starań o odzyskanie pieczy nad dzieckiem, z uwagi na przejęcie funkcji opiekuńczych i zaspokajających potrzeby dziecka przez przedstawicieli podmiotów pieczy. Z uwagi na to, działania wspierające (praca socjalna, poradnictwo specjalistyczne) powinny polegać na wygenerowniu w kliencie (jednostce, czy rodzinie) zdolności do samopomocy, wsparciu $w$ dążeniach do przezwyciężenia trudności, z którymi nie dając sobie samodzielnie rady zwrócił się o pomoc instytucjonalną. Możliwość udzielenia konstruktywnej pomocy zależy od umiejętności i doświadczenia w diagnozowaniu deficytów i potencjału, od zastosowania właściwej metody pracy i motywacji oraz odpowiednich narzędzi (np. poprawnie dobranych świadczeń o charakterze pieniężnym, jak i pomocy niepieniężnej).

Świadcząc pomoc, należy więc pamiętać o jej subsydiarnym charakterze oraz wchodzącej w skład zasady pomocniczości zasadzie subsydiarnej redukcji, polegającej na wycofaniu się ze świadczenia pomocy w sytuacji, kiedy wspierany zaczyna funkcjonować właściwie, uzyskuje niezbędne kompetencje społeczne do samodzielnego przezwyciężenia trudności. Konieczne

${ }^{33}$ Wyrok Wojewódzkiego Sądu Administracyjnego w Lublinie z 17 stycznia 2008 r., syg. akt II SA/Lu744/2007 (http:/ / orzeczenia.nsa.gov.pl). 
jest uchwycenie momentu, w którym z uwagi na poprawę funkcjonowania należy przywrócić rodzicom pieczę nad dzieckiem, aby nie doprowadzić do zbytniego rozluźnienia więzów emocjonalnych oraz utraty kompetencji wychowawczych.

Jedną $\mathrm{z}$ form pomocy zmierzających do uruchomienia zdolności, potencjału człowieka/rodziny jest wspomniana już wielokrotnie praca socjalna, będąca działaniem o charakterze procesualnym i uporządkowanym w cza$\mathrm{sie}^{34}$, celowym i metodycznym oraz realizowanym według specyficznych zasad i $\operatorname{metod}^{35}$.

Problemem wymagającym subsydiarnego wsparcia rodziny przez podmioty systemu pomocowego jest stanowiąca temat rozważań kwestia dysfunkcji rodziny i konieczności skorygowania sposobu wykonywania władzy rodzicielskiej. Profesjonalnie prowadzona praca socjalna pozwala na zrozumienie oraz poznanie istoty problemu danej rodziny, jej indywidualności, niepowtarzalności, ale i pewnej typowości. Konieczne jest więc nowe rozumienie rodziny, będącej zintegrowanym układem relacji o swoistych własnościach i reakcjach, tworzonych na bazie dyskursu jej członków, gdyż umożliwia to poznawanie jej funkcjonalnych i strukturalnych zasad 36 , a co $\mathrm{z}$ tym związane - ukierunkowane działanie pomocowe.

Zgodnie z art. 45 Ustawy o pomocy społecznej, praca socjalna świadczona jest na rzecz poprawy funkcjonowania osób i rodzin $w$ ich środowisku społecznym. Natomiast art. 6 pkt 12 cytowanego aktu prawnego zawiera definicję legalną tego pojęcia, zgodnie z którą jest to działalność zawodowa mająca na celu pomoc osobom i rodzinom we wzmacnianiu lub odzyskiwaniu zdolności do funkcjonowania w społeczeństwie, poprzez pełnienie odpowiednich ról społecznych oraz tworzenie warunków sprzyjających temu celowi.

Praca socjalna stanowi specyficzną działalność zawodową, mającą na celu lepszą adaptację wzajemną osób, rodzin, grup i środowiska społecznego w jakim żyją oraz rozwijanie poczucia godności osobistej i odpowiedzialności jednostek na drodze odwoływania się do potencjalnych możliwości poszczególnych osób lub powiązań międzyprofesjonalnych, a także sił społecznych ${ }^{37}$. Helena Radlińska twierdziła, iż praca socjalna stanowi wydobywanie oraz

34 A. Niesporek, Projekt socjalny, [w:] Praca socjalna wobec wspótczesnych problemów społecznych, red. S. Pawlas-Czyż, Toruń 2007, s. 75.

${ }^{35}$ K. Wódz, Praca socjalna w środowisku zamieszkania, Katowice 1998, s. 13.

${ }^{36} \mathrm{M}$. Gawęcka, Nowe spojrzenie na pracę socjalna zorientowana na rodzinę z perspektywy teorii systemowej i konstruktywizmu, [w:] Praca socjalna. Kształacenie - dziatanie - konteksty, red. A. Kanios, M. Czechowska-Bieluga, Kraków 2010, s. 194.

37 Por. I. Lepalczyk, Niektóre pojęcia z problematyki socjalnej, Warszawa 1981. 
pomnażanie sił ludzkich, ich usprawnianie oraz organizację wspólnego działania dla dobra ludzi ${ }^{38}$.

Bazując na teorii zachowań ludzkich oraz systemów społecznych, praca socjalna ma znaczenie tam, gdzie jednostka/ich grupa wchodzi w interakcje ze środowiskiem ${ }^{39}$.

Praca socjalna może przyjmować zróżnicowane formy - od pomocy doraźnej do długofalowych działań wspierających usamodzielnianie oraz rozwój jednostek i grup społecznych. Klasycznymi jej formami jest praca z indywidualnym przypadkiem, metoda grupowa, metoda polegająca na organizowaniu środowiska. Decyzja o zastosowaniu odpowiedniej formy działania powinna być wypadkową potrzeb i możliwości podmiotów którym się pomaga oraz możliwości osób i instytucji pomagających.

Właściwie zorganizowana, oparta na dogłębnej diagnozie sytuacji konkretnej rodziny pomoc odgrywa istotną rolę aktywizującą jej członków do zmiany niekorzystnej dla nich sytuacji, ale zarazem korygującą dotychczasowe formy i sposoby postępowania rodzica.

Działania prowadzone $\mathrm{w}$ ramach pracy socjalnej $\mathrm{z}$ rodziną dysfunkcyjną zmierzają do wypracowania mechanizmów odpowiedzialności jej członków za swoje działanie oraz do wyposażenia ich w kompetencje pozwalające na podjęcie czynności zmierzających do zabezpieczenia swoich interesów. Wsparcie rodziny z problemem dysfunkcjonalności powinno następować przez odpowiednio dostosowane formy pomocy o charakterze pieniężnym (np. zasiłki okresowe, zasiłki celowe, zasiłek celowy na dożywianie) i niepieniężnym (poradnictwo specjalistyczne, usługi opiekuńcze, pomoc asystenta rodziny), ale zarazem przez wspólne konstruowanie przez beneficjenta i pracownika socjalnego planu realizacji określonych zobowiązań o charakterze samoaktywizującym. Osiągnięciu tego celu służy zawarcie z klientem (rodzicem) kontraktu socjalnego. Określa się w nim sposób współdziałania w rozwiązywaniu problemów osoby lub rodziny znajdujących się w trudnej sytuacji życiowej. Działania te mają zmierzać do wzmocnienia aktywności oraz samodzielności życiowej i zawodowej jednostki, jak również, co niezwykle istotne, przeciwdziałania jej wykluczeniu społecznemu ${ }^{40}$. Nałożone na klienta zobowiązania mogą polegać na konieczności zarejestrowania się $\mathrm{w}$ powiatowym urzędzie pracy $\mathrm{w}$ celu znalezienia zatrudnienia, a co $\mathrm{z}$ tym związane - ubezpieczenia zdrowotnego, czy emerytalnego. Mogą obligować

${ }^{38}$ H. Radlińska, Szkoła pracy społecznej w Polsce 1928, cyt za: B. Szatur-Jaworska, Teoretyczne podstawy pracy socjalnej, [w:] Pedagogika społeczna, red. T. Pilch, I. Lepalczyk, Kraków 1995, s. 106.

${ }^{39}$ D. Wolska-Prylińska, Projekt socjalny $w$ kształceniu i działaniu społecznym, Katowice 2010, s. 22.

${ }^{40}$ Art. 108 Ustawy z 12 marca 2004 r. o pomocy społecznej. 
do poddania się leczeniu, czy terapii, co może wpłynąć na poprawę funkcjonowania jednostki uzależnionej $\mathrm{w}$ rodzinie, wykonywaniu roli rodzica, czy w życiu zawodowym. Mogą to być także zobowiązania do ustalonego kwotowo spłacania zaistniałych zadłużeń czynszowych, opłat za media, które pozwolą na uniknięcie egzekucji komorniczej, czy eksmisji, a tym samym na zapewnienie stabilnego funkcjonowania rodziny i wychowujących się $\mathrm{w}$ niej dzieci.

Beneficjent $w$ ramach prowadzonej $z$ nim pracy socjalnej może liczyć na pomoc ze strony podmiotów wchodzących $\mathrm{w}$ skład systemu pomocy społecznej $\mathrm{w}$ formie porady $\mathrm{w}$ gospodarowniu środkami pieniężnymi (np. świadczeniami rodzinnymi, czy zasiłkami przyznawanymi na podstawie ustawy o pomocy społecznej), w kwestii spłaty i rozłożenia na raty zadłużeń. Może otrzymać pomoc materialną w wysokości zależnej od uzyskiwanego dochodu i usprawiedliwionych potrzeb. W razie konieczności ma możliwość otrzymania wsparcia $\mathrm{w}$ postaci specjalistycznego poradnictwa psychologicznego, prawnego lub rodzinnego.

Przy całym szerokim wachlarzu różnorodnych form pomocy należy pamiętać o ustawowym obowiązku osoby wspieranej do współdziałania $\mathrm{z}$ podmiotami pomocy społecznej $\mathrm{w}$ wyjściu z trudnej sytuacji ${ }^{41}$. Osoby te powinny wykazać aktywność, podjąć ustalone wspólnie z pracownikiem socjalnym działania i zmierzać do realizacji wypracowanych rozwiązań. Powyższe ma prowadzić do wsparcia rodziny w wypełniniu przez nią funkcji zabezpieczających, czy ekonomicznych, pozwalając jej na zaspokojenie podstawowych potrzeb jej członków, w tym przede wszystkim dzieci. Pomoc ta odgrywa rolę edukacyjną, wskazując sposób zarządzania budżetem domowym, kolejność regulownia zobowiązań. Pozwala uwierzyć, że pomimo często niewielkich środków można nimi racjonalnie gospodarować, a dzięki aktywizacji zawodowej klienta, realizowanej we współpracy z właściwym urzędem pracy, zaistnieć także $\mathrm{w}$ roli zawodowej. Pomyślnie przebiegający proces aktywizacji zawodowej, zakończony zdobyciem zatrudnienia, daje szanse na uzyskanie samodzielności materialnej oraz wiąże się z brakiem potrzeby korzystania ze wsparcia państwa. Urzeczywistnia się $\mathrm{w}$ ten sposób tak pożądaną zasadę subsydiarnej redukcji.

$\mathrm{W}$ ramach pracy socjalnej z rodziną, realizując zadania związane z pomocą rodzinie dysfunkcyjnej pracownicy socjalni współpracują z sądem rodzinnym i opiekuńczym. Podmioty działające w systemie pomocy społecznej mogą uzyskać wsparcie formalne ze strony sądu opiekuńczego, wnosząc o wgląd $\mathrm{w}$ sytuację rodziny, czy przy zdiagnozowniu istotnych

${ }^{41}$ Art. 4 ustawy z 12 marca 2004 r. o pomocy społecznej. 
nieprawidłowości o ingerencje $\mathrm{w}$ sposób wykonywania władzy rodzicielskiej przez rodziców dziecka. W swym orzeczeniu sąd może zobowiązać rodziców, czy opiekunów prawnych, do podjęcia działań o charakterze korekcyjnym: współpracy z asystentem rodziny, poddania się terapii (psychologicznej, rodzinnej), skorzystania z pomocy świadczących specjalistyczne poradnictwo psychologów, pedagogów, terapeutów rodziny, czy prawników, jednocześnie wskazując sposób kontrolowania wydanych zarządzeńn ${ }^{42}$. Sąd może poddać wykonywanie władzy rodzicielskiej nadzorowi kuratora sądowego. Współdziałanie pracownika socjalnego i kuratora ustanowionego jako nadzór dla danej rodziny ma ogromne znczenie dla pożądanego przebiegu procesu pomocowego.

Deficyt uwagi rodzicielskiej, zainteresowania problemami dziecka (emocjonalnymi, zdrowotnymi, szkolnymi), wynikający z powołanych już w niniejszych rozważaniach przyczyn, jest jednym z czynników generujących niedostosowanie społeczne dziecka, czy jak ujmuje to ustawa o postępowaniu w sprawach nieletnicch - jego demoralizację. Niedostosowanie społeczne nieletniego, stanowiące wadliwe funkcjonowanie jednostki, wyrażające się $\mathrm{w}$ nieadekwatnym odgrywaniu przez nią przypisanych jej ról społecznych ${ }^{43}$, stanowi istotny problem wymagający wdrożenia działań o charakterze zapobiegawczo-korekcyjnym. W sytuacji tej niezbędne będzie udzielenie pomocy rodzinie przez objęcie jej pracą socjalną, wsparciem asystenta rodziny, podjęcie współpracy ze szkołą i kuratorem nadzorującym nieletniego (jeżeli taki środek został przez sąd orzeczony) oraz wspólne poszukanie rozwiązania zaistniałych problemów.

Pomoc udzielana rodzicom dziecka $\mathrm{w}$ formie pracy socjalnej powinna być $\mathrm{w}$ wielu przypadkach wsparta dodatkowo specjalistycznym poradnictwem.

Poradnictwo specjalistyczne stanowi niepieniężną formę pomocy przewidzianą przepisami ustawy o pomocy społecznej. Jest ono postrzegane jako instytucjonalny system o określonej strukturze organizacyjnej, ale także jako specyficzna czynność podejmowana przez profesjonalnych doradców ${ }^{44}$. Pomoc $\mathrm{w}$ formie poradnictwa przewidziana została $\mathrm{w}$ art. 46 Ustawy o pomocy społecznej. Poradnictwo świadczone jest w zakresie zagadnień prawnych, psychologicznych oraz rodzinnych osobom i rodzinom, które mają trudności lub wykazują potrzebę wsparcia w rozwiązaniu swoich problemów życiowych ${ }^{45}$.

42 Art. 109 §2 pkt 1 K.r.o.

${ }^{43}$ L. Pytka, Pedagogika resocjalizacyjna. Wybrane zagadnienia teoretyczne, diagnostyczne i metodyczne, Warszawa 2000, s. 22-23.

44 T. Pilch, I. Lepalczyk (red.), Pedagogika społeczna, Warszawa 1995, s. 320.

${ }^{45}$ Art. 46 Ustawy z 12 marca 2004 r. o pomocy społecznej. 
Beneficjent wraz z udzielającym porady prawnikiem poszukuje powodów wystąpienia problemu o charakterze prawnym, dotyczącego wykonywania władzy rodzicielskiej, zaistnienia podstawy wydania orzeczenia o ingerencji we władzę rodzicielską rodziców (ograniczenia jej lub pozbawienia), czy zastosowania środka wychowawczego w sprawach nieletnich (w sytuacji stwierdzenia przez sąd demoralizacji dziecka).

Korzystajacy ze specjalistycznego poradnictwa prawnego beneficjenci uzyskują świadomość problemu, który przy wsparciu organu pomocy społecznej starają się rozwiązać. Dowiadują się, co stanowiło podstawę zaingerowania organów państwa w wykonywaną przez nich władzę rodzicielską, jaki jest zakres ich obowiązków wobec małoletniego. Poradnictwo daje także możliwość podjęcia działań zmierzających do ochrony ich praw, także tych związanych z wykonywaniem władzy rodzicielskiej.

Porada prawna zawiera $w$ sobie także elementy edukacyjne. $W$ jej trakcie następuje zapoznanie klienta z procedurami działania poszczególnych organów państwa oraz sposobami uzyskania wsparcia i ochrony prawnej. Jest nakierowana na zobiektywizowanie obrazu sytuacji beneficjenta na gruncie obowiązujących regulacji prawnych i poinformowanie go o skutkach prawnych poszczególnych zaproponowanych rozwiązañ ${ }^{46}$. Porada prawna może mieć charakter dyscyplinujący klienta i skłaniający go do terminowego podjęcia działania, gdyż nieprzestrzeganie ustalonych reguł będzie wiązać się z negatywnymi skutkami prawnymi (np. pozostawieniem wniosku bez rozpoznania, zwrotem nieuzupełnionego pisma procesowego itp.).

Zakres udzielanej porady jest zależny od specyfiki podjętego problemu oraz, co równie istotne, od możliwości intelektualnych i kompetencji beneficjenta. Czasami może to być jednorazowa konsultacja, polegająca na werbalnym wskazaniu klientowi kierunku działania. Zdarza się jednak, iż rodzic czy rodzice, którzy zwrócili się o udzielenie pomocy mają problem $\mathrm{z}$ wypowiedzią $\mathrm{w}$ formie pisemnej (jak np. problem analfabetyzmu lub wtórnego analfabetyzmu). Zdarza się, że klientowi sprawia trudność czynność czytania tekstu ze zrozumieniem oraz na tej podstawie fromułowanie planu podejmowania dalszych działań. Pomoc w omawianym zakresie polega na wytłumaczeniu zaistniałego problemu i wskazaniu formalnie dopuszczalnego rozwiązania. Rodzice potrzebują pomocy w zrozumieniu treści formularzy wniosków o pomoc $\mathrm{w}$ postaci świadczenia rodzinnego i dodatków do niego, wyjaśnienia procedur związanych z nabyciem świadczenia $\mathrm{z}$ funduszu alimentacyjnego.

${ }^{46} \mathrm{~J}$. Rajewska de Mezer, Rola poradnictwa prawnego jako formy wsparcia beneficjenta pomocy społecznej, [w:] Poradnictwo. Kolejne przybliżenia, red. M. Piorunek, Torun 2011, s. 189-190. 
Zmierzając do aktywizującego, konstruktywnego wsparcia jednostki, nie należy zapominać o funkcjonującej w pomocy społecznej, wspomnianej wyżej, zasadzie pomocniczości, polegającej na wspieraniu klienta w wyjściu $\mathrm{z}$ problemu, uruchamianiu jego potencjału oraz kompetencji do działania.

Zbyt szerokie ingerowanie, narzucanie rozwiązań, jako obiektywnie właściwych, może doprowadzić do wytworzenia $\mathrm{w}$ beneficjencie poczucia braku decyzyjności, a co z tym związane - braku odpowiedzialności za działanie. Pojawia się groźba wystąpienia, tak niepożądanego przez udzielających pomocy, zjawiska wyuczonej bezradności.

$\mathrm{W}$ sytuacji dysfunkcji rodziny praca socjalna $\mathrm{z}$ rodziną oraz poradnictwo, w tym również prawne, mogą wpływać na pożądane zmiany sposobu wykonywania zadań przez rodziców, uświadamiać im zakres ich praw i obowiązków wobec niepełnoletnich dzieci.

Pomoc $\mathrm{w}$ formie poradnictwa ma zmierzać do nakreślenia zakresu obowiązków rodzicielskiech, czasmi zmiany sposobu ich postrzegania. Właściwa diagnoza deficytów i potrzeb danej rodziny, problemów z jakimi się boryka (zdrowotnych, zawodowych, wychowawczych), pozwala na ukierunkowanie pomocy $\mathrm{w}$ celu podjęcia przez rodziców właściwego, pożądanego prawnie i społecznie sprawowania funkcji rodzicielskich. Waga tych działań jest o tyle znacząca, że funkcjonowanie rodziców wpływa bezpośrednio na kształtowanie dziecka i przejęcie przez nie wzorów ról społecznych, a więc rzutuje na jego dalsze życie i funkcjonowanie w społeczeństwie.

Odpowiednie działania wychowawcze rodziców, właściwe wypełnianie przez nich ustawowych obowiązków pieczy nad osobą dziecka, jego majątkiem oraz oparta na zasadzie dobra dziecka reprezentacja, stanowią czynnik istotny $\mathrm{w}$ przeciwdziałaniu wystąpienia wspomnianego powyżej zjawiska niedostosowania społecznego, czy demoralizacji dziecka. Zgodnie z regulacjami Konstytucji RP rodzice mają prawo do wychowywania swojego dziecka zgodnie ze swymi przekonaniami ${ }^{47}$. Powinni wyposażać je $\mathrm{w}$ wiedzę dotyczącą obowiązujących norm, wartości, którymi kierować powinno się dziecko w życiu, szczególnie wchodząc w dorosłość społeczną. Wsparcie dostarczone przez rodziców oraz monitorowanie działań i zachowań dziecka jest jednym z kluczowych czynników chroniacych przed podejmowaniem przez dzieci i młodzież zachowań ryzykownych. Wspieranie, o którym mowa, może następować poprzez wzmacnianie poczucia własnej wartości dziecka, udzielanie pomocy w bezpośredni, ale zarazem konstruktywny sposób oraz zapewnianie dziecku poczucia bezpieczeństwa, ciepła i akceptacji48.

${ }^{47}$ Art. 48 Konstytucji Rzeczpospolitej Polskiej z 2 kwietnia 1997 r.

${ }^{48}$ K. Ostaszewski, A. Pisarska, Relacje w rodzinie a syndrom zachowań ryzykownych okresu adolescencji, [w:] Dylematy i wyzwania wspótczesnej resocjalizacji, red. K. Sawicki, R. Ćwikowski, A. Chańko, Białystok 2015, s. 116. 
W wielu przypadkach rodzice sami nie są $\mathrm{w}$ stanie przezwyciężyć barier pozwalających im na obronę praw swoich i ich dzieci. Może to wynikać z towarzyszących im deficytów o różnej genezie. Potrzebują wówczas wsparcia dostosowanego do indywidualnie zdiagnozowanych potrzeb. Często trudności spowodowane są małą świadomością jednostki i brakiem wiary w możliwość wpływu na zmianę zaistniałej sytuacji, niskimi kompetencjami intelektualnymi (niepełnosprawność intelektualna) lub społecznymi.

W tym zakresie właściwą pomoc stanowi wspomniane już w niniejszej pracy specjalistyczne poradnictwo prawne. Porady prawne dotyczą problemów prawa rodzinnego, ze szczególnym uwzględnieniem problematyki procedury oraz skutków prawnych rozwodu, czy separacji, kwestii związanych z koniecznością zaspokojenia podstawowych potrzeb rodziny poprzez ustalenie i zobligowanie do uiszczania renty alimentacyjnej, kwestii wykonywania władzy rodzicielskiej oraz ingerencji w jej wykonywanie ${ }^{49}$, a także problemu regulowania kontaktów pomiędzy rodzicami i dziećmi. Właściwe uregulowanie formalne problemu wykonywania władzy rodzicielskiej przez oboje rodziców oraz sposobu realizowania prawa do kontaktu z dzieckiem ma niezaprzeczalne znaczenie dla rozwoju dziecka, kształtowania jego tożsamości i wzorów ról społecznych w rodzinie. Wsparcie rodziców przez udzielającego porady prawnej, uświadomienie im znaczenia udziału obojga rodziców $\mathrm{w}$ procesie wychowawczym oraz praw i obowiązków wynikających z wykonywanej pieczy pozwala na skorygowanie zachowań niepożądanych, wprowadzenie zasad współpracy rodziców w wychowaniu dzieci (szczególnie kiedy nie żyją w związku i zamieszkują osobno).

Rodzice korzystają także ze wsparcia, w formie poradnictwa, wobec realizacji uprawnień związanych $\mathrm{z}$ niepełnosprawnością (ich samych lub dziecka), w zakresie sporządzania wniosków o ustalenie niepełnosprawności, stopnia niepełnosprawności, odwołań od decyzji odmawiających przyznania im statusu osoby niepełnosprawnej, w sprawach dotyczących postępowań o nabycie świadczeń związanych z niepełnosprawnością lub niezdolnością do pracy. Pomoc w omawianym zakresie pozwala na uregulowanie sytuacji prawnej, ekonomicznej osoby niepełnosprawnej w rodzinie, co wpływa często na funkcjonowanie całej rodziny i wykonywane przez nią funkcje.

W ramach porady prawnej klienci mogą uzyskać informacje o podmiotach, instytucjach i procedurach, które mogą wesprzeć ich w działaniach zabezpieczających ich prawa, diagnostyce i leczeniu (np. działaniu zespołów interdyscyplinarnych przeciwdziałania przemocy $\mathrm{w}$ rodzinie, działaniach

${ }^{49}$ Art. 109, 110 i 111 Ustawy z 25 lutego 1964 r. Kodeks rodzinny i opiekuńczy. 
komisji rozwiązywania problemów alkoholowych, procedurze niebieskiej karty, działaniach podejmowanych wobec dłużnika alimentacyjnego, działaniach powiatowych/miejskich zespółów do spraw orzekania niepełnosprawności itp.). Poradnictwo dotyczy też kwestii ekonomicznych rodziny związanych z zaciągniętymi zobowiązaniami kredytowymi, czy pożyczkowymi niespłacanymi przez klienta, co może skutkować wszczęciem postępowania egzekucyjnego i zachwiać bezpieczeństwem funkcjonowania rodziny. Wsparcie prawne potrzebne jest także rodzinom $\mathrm{w}$ zakresie problemów prawa pracy. Utrata pracy, działania o charakterze dyskryminacji, czy mobbingu stosowane wobec pracownika wpływają na funkcjonowanie jego i rodziny, standard jej życia, możliwość zaspokojenia podstawowych potrzeb, atmosferę pomiędzy jej członkami i wypełnianie innych funkcji. Pomoc w tej dziedzinie może wpłynąć bezpośrednio lub pośrednio na normalizację sytuacji w innych sferach funkcjonowania pracownika - ojca, partnera związku. Właściwie ukierunkowana porada prawna $\mathrm{w}$ omówionych zakresach znajduje odzwierciedlenie w sposobie wykonywania ról w rodzinie.

Beneficjenci poza pomocą $\mathrm{w}$ formie poradnictwa prawnego wymagają także wsparcia psychologicznego, czy terapeutycznego, które świadczone jest $\mathrm{w}$ postaci poradnictwa o charakterze psychologicznym, czy rodzinnym. Często nie potrafią rozwiązać narastających problemów związanych z funkcjonowaniem rodziny (np. nie radzą sobie ze skutkami niewydolności wychowawczej, uzależnieniami, utratą zatrudnienia, brakiem umiejętności funkcjonowania w poszczególnych rolach społeczych). Występuje frustracja wynikająca ze świadomości braku wpływu na pojawienie się niepożądanej sytuacji, a w ślad za nią agresja i czyny noszące znamiona przestępstwa znęcania, naruszenia nietykalności cielesnej itp.

Poradnictwo psychologiczne realizuje się przez procesy diagnozowania, profilaktyki i terapii ${ }^{50}$. Umożliwia zrozumienie emocji, które kierują człowiekiem oraz ich związku z reakcją na sytuację stresu i frustrację wynikającą $\mathrm{z}$ problemów $\mathrm{z}$ adaptacją społeczną. $\mathrm{W}$ wyniku uzyskania pomocy $\mathrm{w}$ tej formie możliwa jest diagnoza pacjenta pod względem zdrowia psychicznego oraz $\mathrm{w}$ razie potrzeby skierowania go na dalszą diagnostykę lub leczenie ambulatoryjne, czy całodobowe-szpitalne. Pozwala także na włączenie działań psychoterapeutycznych i leczenia farmakologicznego. Właściwe funkcjonowanie psychiczne partnerów związku, rodziców dziecka ma bowiem istotny wpływ na poprawne wykonywanie prawnie i społecznie określonych zadań rodziny, atmosferę wychowawczą, przekazywanie wzorów ról społecznych.

${ }^{50}$ Art. 46 ust. 3 Ustawy z 12 marca 2004 r. o pomocy społecznej. 
Natomiast, wspomniane wyżej poradnictwo rodzinne obejmuje szeroko rozumiane problemy funkcjonowania rodziny, w tym problemy wychowawcze $w$ rodzinach naturalnych i zastępczych oraz problemy opieki nad osobą niepełnosprawną, a także terapię rodzinną ${ }^{51}$. Jego celem jest zrozumienie mechanizmów wpływających na interakcje występujące pomiędzy członkami rodziny, odmienności $\mathrm{w}$ prezentowanych przez poszczególne osoby wzorach ról społecznych, postawach wobec istotnych kwestii życiowych.

Konkludując, celem pracy socjalnej prowadzonej z rodziną dysfunkcyjną opierającą się na podmiotach pomocy społecznej oraz świadczonego na jej rzecz poradnictwa specjalistycznego (w tym prawnego), powinno być doprowadzenie do oczekiwanej społecznie, świadomej zmiany sposobu wykonywanej roli rodzica, wynikającej ze zrozumienia znaczenia zasady priorytetowej jaką jest dobro dziecka i roli rodzica $w$ procesie kształtowania osobowości dziecka i jego kompetencji społecznych.

$\mathrm{Z}$ uwagi na powyższe, $\mathrm{w}$ celu konstruktywnego wsparcia rodziny, w której zdiagnozowano deficyty w wypełnianiu niektórych lub większości przypisanych jej funkcji, należy:

1) dokonywać dogłębnej analizy sytuacji tej rodziny w różnych aspektach jej funkcjonowania oraz określić obszary deficytowe;

2) projektować działania wspierające ukierunkowane na usunięcie przyczyny dysfunkcji rodziny, oparte na indywidualnym skonstruowanym planie pracy z rodziną, uwzględniającym zasadę pomocniczości oraz dopuszczającym ingerencję $\mathrm{w}$ wykonywanie władzy rodzicielskiej dla potrzeb korekcyjno-pomocowych;

3) stosować wsparcie polegające na uzupełnianiu się różnych form pomocy rodzinie, przede wszystkim pracy socjalnej z rodziną wspartej poradnictwem specjalistycznym i działaniami terapeutycznymi, wspomaganymi - w razie konieczności - świadczeniami o charakterze pieniężnym;

4) uświadomić - $w$ ramach świadczonego poradnictwa - wspieranym członkom rodziny istotę i genezę problemu, który spowodował podjęcie działań ingerencyjno-wspierających, znaczenie aktywnej roli danej rodziny $\mathrm{w}$ rozwiązaniu określonego problemu oraz utwierdzić ich $\mathrm{w}$ przekonaniu o możliwości wpływu na otaczającą ich rzeczywistość przez podejmowanie określonych działań formalnych (działania te muszą być jednak poprzedzone przygotowaniem klienta do aktywnego przyjęcia pomocy $\mathrm{w}$ drodze poradnictwa i pracy socjalnej);

${ }^{51}$ Art. 46 ust. 4 Ustawy tamże. 
5) oprzeć aktywizujące rodzinę wsparcie na współpracy pomiędzy otoczoną oparciem rodziną oraz podmiotami pomocy społecznej - sądem rodzinnym, kuratelą sądową oraz podmiotami systemu oświaty (szkoły, przedszkola), bowiem efektywność oddziaływań korekcyjno-wspierających wymaga, z uwagi na interdyscyplinarność problematyki, współdziałania specjalistów różnych dziedzin oraz wymiany między nimi doświadczeń i informacji.

Albowiem, tylko rodzina świadoma swoich praw, sytucji prawnej, ale co najważniejsze - obowiązków wobec swojego dziecka, objęta działaniami edukacyjnymi oraz $\mathrm{w}$ razie konieczności pomocowymi czy korekcyjnymi może wypełniać właściwie swoje funkcje wobec wychowujących się w niej dzieci, wpływając na ich pożądany rozwój oraz kształtowanie ich tożsamości indywidualnej i społecznej.

\section{BIBLIOGRAFIA}

Adamski F., Socjologia małżeństwa i rodziny, Warszawa 1982.

Ambrozik W., Readaptacja społeczna i reorganizacja środowisk lokalnych jako warunek skuteczności oddziatywań resocjalizacyjnych, [w:] Resocjalizacja, t. 2, red. B. Urban, J.M. Stanik, Warszawa 2007.

Andrzejewski M., Prawo rodzinne i opiekuńcze, Warszawa 2014.

Bednarski H., Rodziny polskie w procesie przemian, [w:] Wybrane obszary dysfunkcjonalności rodziny, red. M. Dudek, Krasnystaw 2010.

Cęcelek G., Rodzina - jej problemy oraz zagrożenia wychowawcze, Mazowieckie Studia Humanistyczne, 2005, 1-2.

Cudak H., Zewnetrzne uwarunkowania wewnątrzrodzinnej socjalizacji $i$ wychowania dzieci, [w:] Wokót wychowania. Rola rodziny $i$ szkoty w procesie socjalizacji dziecka, red. T. Rostowska, J. Rostowski, Łódź 2006.

Gawęcka M., Nowe spojrzenie na prace socjalna zorientowana na rodzinę z perspektywy teorii systemowej i konstruktywizmu, [w:] Praca socjalna. Kształacenie - działanie - konteksty, red. A. Kanios, M. Czechowska-Bieluga, Kraków 2010.

Harwas-Napierała B., Rodzina jako wartość w rozwoju człowieka, Poznań 2009.

Kawula S., Brągiel J., Janke A.W., Pedagogika rodziny, Torun 2002.

Kaźmierczak T., Polityka pomocy społecznej wobec rodziny we wspótczesnej Polsce, [w:] Praca socjalna. Pomoc społeczna, red. J. Kwaśniewski, Katowice 1998.

Konstytucja Rzeczpospolitej Polskiej z 2 kwietnia 1997 r. (DzU 1997, nr 78, poz. 483).

Kowalski S., Socjologia wychowania w zarysie, Warszawa 1974.

Lalak D., Pilch T. (red.), Elementarne pojęcia pedagogiki społecznej i pracy socjalnej, Warszawa 1999.

Matyjas B., Pedagogika społeczna i rodzina - obszary badań, [w:] Pedagogika społeczna - podręcznik akademicki, t. II, red. E. Marynowicz-Hetka, Warszawa 2007.

Niesporek A., Projekt socjalny, [w:] Praca socjalna wobec wspótczesnych problemów społecznych, red. S. Pawlas-Czyż, Torun 2007.

Olechnicki K., Załęski P., Stownik socjologiczny, Toruń 2000. 
Ostaszewski K., Pisarska A., Relacje w rodzinie a syndrom zachowań ryzykownych okresu adolescencji, [w:] Dylematy $i$ wyzwania wspótczesnej resocjalizacji, red. K. Sawicki, R. Ćwikowski, A. Chańko, Białystok 2015.

Pilch T., Lepalczyk I. (red.), Pedagogika społeczna, Warszawa 1995.

Pytka L., Pedagogika resocjalizacyjna. Wybrane zagadnienia teoretyczne, diagnostyczne $i$ metodyczne, Warszawa 2000.

Rajewska de Mezer J., Rola poradnictwa prawnego jako formy wsparcia beneficjenta pomocy społecznej, [w:] Poradnictwo. Kolejne przybliżenia, red. M. Piorunek, Torun 2011.

Rajewska de Mezer J., Rola poradnictwa specjalistycznego we wsparciu rodziny w funkcji wychowawczej, [w:] Młodzież między ryzykiem a ochrona. Formy wsparcia psychopedagogicznego dla adolescentów, red. A.Matysiak-Błaszczyk, B. Jankowiak, Poznań 2017 (w dru$\mathrm{ku})$.

Rajewska de Mezer J., Flaga E., Rola edukacyjna pomocy społecznej we wsparciu rodzin osob niepetnosprawnych, Studia Edukacyjne, 2013, 26.

Rembowski I., Więzi uczuciowe w rodzinie. Studium psychologiczne, Warszawa 1972.

Sierpowska I., Ustawa o pomocy społecznej. Komentarz, Warszawa 2007.

Szacka B., Wprowadzenie do socjologii, Warszawa 2003.

Szatur-Jaworska B., Teoretyczne podstawy pracy socjalnej, [w:] Pedagogika społeczna, red. T. Pilch, I. Lepalczyk, Kraków 1995.

Sztander W., Rodzina z problemem alkoholowym, Warszawa 2006.

Tyszka Z., Socjologia rodziny, Warszawa 1974.

Ustawa z 25 lutego 1964 r. Kodeks rodzinny i opiekuńczy (DzU 2015, poz. 2082 ze zm.).

Ustawa z 12 marca 2004 r. o pomocy społecznej (DzU 2016, poz. 930 ze zm.).

Ustawa z 9 czerwca 2011 r. o wspieraniu rodziny i systemie pieczy zastępczej (DzU 2015, poz. 332 ze zm.).

Wolska-Prylińska D., Projekt socjalny w kształceniu i działaniu społecznym, Katowice 2010.

Wódz K., Praca socjalna w środowisku zamieszkania, Katowice 1998.

Ziemska M., Rodzina a osobowość, Warszawa 1975. 